DOI https://doi.org/10.18551/rjoas.2017-09.03

\title{
CORPORATE GOVERNANCE AND ENVIRONMENTAL PERFORMANCE IN THE CONTEXT OF ASEAN ECONOMIC COMMUNITY
}

\author{
Muliati ${ }^{*}$ Pattawe Abdul, Mile Yuldi, Lucyani \\ University of Tadulako, Indonesia \\ *E-mail: muli ak@yahoo.com
}

\begin{abstract}
ASEAN economic community is the opportunity for Indonesia to integrate the economy. This encourages Indonesian companies to have superiority to competing in the ASEAN. The objective of this study is to describe corporate governance and environmental performance in terms of AEC. This study used literature review as the research method. The data were collected from various references toward the practice of Asean Economic Community (AEC). The result shows that there is an increase of corporate governance index and the achievement of environmental performance rating from various companies assessed by Corporate Environmental Performance Ratings (PROPER) in 2014-2015 and Environmental Performance Index (EPI). This proves that Indonesian companies have been ready to face the AEC.
\end{abstract}

\section{KEY WORDS}

AEC, corporate governance, environmental performance.

Corporate governance is still a hotspot among shareholders, regulators, and the community and it significantly increases attention during the last decade (Smolo and Smajic, 2011). Good corporate governance will elevate the investor confidence, help small shareholders, and encourage good decision-making process. In addition, it also repairs the relationship between workers, creditors, and the other stakeholders (Yacob and Basiuni, 2014). According to Nurhaida (2015), corporate governance with the best standard will be one of the determinant factors for the issuer to face the AEC (www.ojk.go.id). AEC will be an opportunity and threat for companies in the ASEAN. Companies which have good governance will treat AEC as the opportunity, but those with poor governance will see it as a threat.

Public awareness of the importance of environmental management makes companies pay attention the corporate governance considering environmental issues. Information of environmental performance of ASEAN countries has been getting attention from researchers like Ab-Rahim (2014); Said (2014). Environment condition will affect investor to make a decision (Said et.al. 2014). Environmental information is useful for policy makers to repair their design of environmental policy and for long-terms sustainability of a nation. Ab-Rahim (2014) stated that countries with smaller economies like Laos, Cambodia, and Brunei are a country with efficient environmental management. In accordance with economic efficiency, countries with larger economies like Malaysia, Indonesia, Philippines, and Singapore is more efficient than the small countries (except Brunei).

This study will discuss the problem of corporate governance and environmental performance in the AEC.

\section{METHODS OF RESEARCH}

This study used literature review as the research method. The data were collected from various references related to the corporate governance, environmental performance, and Asean Economic Community. The time frame was in 2014-2015. The data collected would be analyzed descriptively to provide a view on the achievement of corporate governance and environmental performance in the AEC. 


\section{DISCUSSION OF RESULTS}

ASEAN Economic Community. Free trade era has been entering into force all over the world. This also encourages member states of ASEAN to initiate the program of AEC as the form of regional economic integration planned to achieve in 2015. Indonesian companies surely have to prepare to compete in the AEC.

The practice of AEC will be an opportunity and at the same time threat for Indonesia. An opportunity of goods exchanges among the countries will be created when there are only small obstacles to import or export them. The challenge faced by the member states of ASEAN is the homogeneity of circulating goods so that the products are demanded to have high quality to be marketable in this ASEAN free trade.

AEC will be a good opportunity for Indonesia as the trade obstacle decreases and event there is no again. This will affect the enhancement of export so that the wider the market area of Indonesian products, the higher the exchange resulted. On the other hand, another challenge is the problem of homogeneity of the commodity which is sold and bought so that there is a demand for a better quality to win the competition in the ASEAN.

The competition in the Asean Economic Community demands Indonesian companies to repair the business process to provide a product or service which have a competitive advantage. Due to the practice of AEC, companies around the state members of ASEAN will be a competitor of Indonesian companies. For that reason, considering matters which can support competitive advantage being the priority of Indonesian company is a must.

Competitive advantage can be achieved through the occurrence of a business process which conforms business regulations and those determined by the regulator. In this case, corporate governance as a regulation will be an important thing to achieve the sustainability of a company. Through the existence of good corporate governance, asset security will be achieved and the enhancement of long-terms shareholders value will occur (Effendi, 2009:1).

The regulation determined by the regulator is commonly in the form of responsibility and environment fulfillment. In particular, the implementation of good environmental business will get an attention from stakeholders. Companies which comply regulation required by the regulator will get a good rating. This surely will have an impact on the companies competitiveness. There have been many studies which prove that the establishment of good environmental business will enhance companies performance as the effect of the advantage gotten from the business performance which implies the regulation (Jo and Harjoto, 2011; Gunawan (2015).

ASEAN Corporate Governance. The Organization for Economic Co-operation and Development (OECD) states that "Corporate governance involves a set of relationships between a company's management, its board, its shareholders and other stakeholders. Corporate governance also provides the structure through which the objectives of the company are set, and the means of attaining those objectives and monitoring performance are determined." (OECD, 2004)

The existence of ASEAN integration and free investment environment makes corporate governance stand out as the main discriminating factor which influences the condition where the company can access capital market and the investor can participate to create company value. The standard of ASEAN corporate governance will remain as the main priority in an effort to strengthen ASEAN global competitiveness and to enhance the visibility of ASEAN.

The regulatory framework of corporate governance has to encourage transparency and efficient market, in accordance with law, and to clearly divide obligation and responsibility between the authority running the supervision function, regulation and law enforcement (OECG, 2004). This is the basis for determining a corporate governance framework in Indonesia by using the principles of transparency, accountability, responsibility, independence, and equity and fairness (KNKG, 2006).

ASEAN Capital Market Forum (ACMF) is an association of capital market regulator in the ASEAN. Agreement in ACMF implementation plan aims to realize ASEAN as the one and only economic community in 2015. 
ASEAN Corporate Governance (CG) Scorecard is the program initiated by ACMV; its members are the regulator of the capital market in the ASEAN. This scorecard also has been used to assess the practice of CG of open companies in other ASEAN countries, such as Philippines, Malaysia, Singapore, Thailand, and Vietnam.

Indonesia has shown its high commitment toward the improvement of corporate governance standard which is accordance with the aspiration of corporate governance of Asean capital Market forum (ACMF). Financial Services Authoritys (OJK) has strengthened the regulatory framework for the implementation of good corporate governance in Indonesia through the existence of regulation amendment and the introduction of new regulation.

There are four regulations of corporate governance to the companies listed in stock exchange (public company), namely:

- Financial Services Authoritys (OJK) regulation No.32/POJK/04/2014 on Shareholders General Meeting.

- Financial Services Authoritys (OJK) regulation No.33/PJOK.04/2014 on management and board of commissioners.

- Financial Services Authoritys (OJK) regulation No.34/PJOK.04/2014 on Nomination and Remuneration Committee.

- No.33/PJOK.04/2014 on the corporate secretary.

Those regulations were effectively entered into force on December 2014. Another initiative of road map corporate governance Indonesia is the existence of corporate governance regulation for the public company issued on June 2015. This promotes the adoption of best practices corporate governance among the Indonesian public companies.

The Indonesian Institute for Corporate Directorship (IICD) as the domestic rating agency pointed by OJK plays an important role to enhance the importance of GCG practice and to encourage public companies to adopt ASEAN CG Scored. Efforts performed by IICD are:

- Actively participating in the enhancement of road-map corporate governance Indonesia.

- Providing technical skill to declare regulation and corporate governance regulation for public companies.

- Continuously clarifying the practice of new regulation to the Indonesian public companies, and

- Providing training in ASEAN Corporate Governance Scorecard for Indonesian Public Companies.

The principle of corporate governance assessment of ASEAN Corporate Governance Scorecard is adopted from corporate principles developed by the Organization for Economic Co-operation and Development (OECD): Rights of shareholders, Equitable treatment of all shareholders, Stakeholders' role, Disclosure and Transparency, and board of commissioners and Board of director's responsibility (OECD, 2004).

Rights of Shareholders. Rights of shareholders both majority and minority in the corporate governance framework has to be reserved. Those rights comprised the right to get security guarantee of the method of ownership registration, to transfer and hand over the ownership of share, to get relevant information about the company periodically and regularly, to participate and give vote in the general meeting of shareholders, to select the members of board of commissioners and board of directors, to share the companies' profit.

Healthy corporate governance system makes shareholder actively participate and give an impact to the company decision-making process (Zhuang et al., 2000).

Equitable treatment of all shareholders. Corporate governance framework has to make sure the equitable treatment of all shareholders including those who are a minority and foreign ownership. Shareholders who have the same classification get fair treatment. Shareholders have to be protected from fraud, self-dealing, and insider trading conducted by the board of directors, manager, the main shareholders, or other parties who have information access. In addition, companies also have to transparently reveal the openness in terms of a transaction with conflicting interests. 
Shareholders have to be treated fairly in accordance with equity principle. For that matter, shareholders have to own a full right which is not violated to give one voice for every share. Companies have to provide information needed to the shareholders so that permitting the give of beneficial voice.

All shareholders have to get equitable treatment without considering the number of majorities or minority ownership, as do the openness of beneficial information providing and there is no allotment to share or stock sale by insider trading. This will be realized by issuing company's regulation that protects minority interest.

Stakeholders' Role. Corporate Governance framework has to give certainty that stakeholders and the community are protected by law and to encourage active cooperation between company and stakeholder to enhance welfare, prosperity, job vacancy and company's adequate financial ability. As a result, in the corporate governance, stakeholders' right is reserved and their interest is respected. When the stakeholders' interest reserved is violated by other sides, the stakeholders have to own fair problem solving; in addition, they have to be encouraged to participate in the company. The implementation of corporate governance has to acknowledge stakeholders' right fixed by law or through joint agreement and to encourage active cooperation between company and stakeholder to achieve wealth, job, and company financial sustainability.

According to OECD (2004), the key aspect of corporate governance is making sure the external stream capital for a company, both equity, and credit. Corporate governance also finds ways to encourage stakeholders within a company to economically perform optimal levels of specific resource investments and physical capital within a company. Competitiveness and the success of a company are the results of cooperation between investors, employees, creditors, and vendors who jointly give a contribution.

A company has to acknowledge that stakeholders' contribution is the precious resources to achieve goals. As a result, for long-terms interest, a company has to encourage cooperation to result in prosperity among stakeholders. Corporate governance framework has to acknowledge that company's interest is served by admitting stakeholder's interest and their contribution to the success of long-terms success.

Disclosure and Transparency. Corporate governance framework has to make sure the disclosure of accurate and just-in-time company's material information, among other things financial situation company performance, shareholders, and company management and risk factor might appear. Material information that needs to be disclosed includes financial result and company activities, controlling shareholders, members of the board of directors and executive, the risk might happen, company's structure and target which want to be achieved.

The information has to be disclosed and presented in accordance with the international or national standard which has high quality. In addition, annual company audit has to be performed by an independent auditor. A company also has to spread information fairly, timely, and affordable for users who want to access it.

The implementation of corporate governance has to make sure that the just-in-time and accurate disclosure was applied at all of the material things related to the company. Clear and just-in-time information provided to shareholders will give an effect on decision making both by shareholders themselves and investor candidates.

Shareholders have an important role within the company and active cooperation with stakeholder will result in a healthy company from the aspect of finance. These principles are realized with the consciousness that responsibility is a logical consequence of the existence of authorities, understanding that there is a social responsibility, avoiding the abuse of office, being a professional and respecting attitude, caring for the healthy business environment.

Board of commissioners or Board of Director's Responsibility. Board of directors has to effectively supervise the company and responsible to the shareholders. The members of the board of directors have to act transparently, to do something in good faith, to have performed due diligence and in the best method of their version. Board of directors responsible to accentuate the interest of shareholders and make sure that company performs its activities. In addition, board of directors also has to fulfill several functions of principle supervision, namely: 
- Studying company's strategy, principle action planning, risk policy of annual budget and business plan, stipulating goals, reviewing implementation and company performance and monitoring high income of company, acquisition, and investment.

- Selecting, giving compensation and monitoring if needed is able to change executives and monitoring substitution plan of company's executive.

- Monitoring and handling conflicting interests between the management of the board of directors' members and shareholders that might appear including abuse of transaction with an affiliated side.

- Monitoring the effectiveness of corporate governance implementation and doing some changes if needed.

- Board of directors considers the assignment given to executive officers in sufficient quantities or able to independently implement and stabilize conflicting interest might occur.

Assessment Analysis of Corporate Governance. Assessment Analysis of Corporate Governance decision-making by Indonesian Institute of Corporate Directorship. In 2014, the number of public companies assessed was 550 , it was $4 \%$ much more than assessed in 2013. The number of the public company assessed is not distributed proportionately since the lack of English version which causes Vietnam has less than 100 public companies assessed (Figure 1). The public companies assessed are those which adopt ASEAN Corporate Governance, consisting of ASEAN Corporate Governance Scorecard and ASEAN public companies assessment has shown significant enhancement in adopting best practice corporate governance. Public companies with good corporate governance have been collecting lots of share buyers which will decrease the market susceptibility to the financial crisis, strengthening the right to own, decreasing capital cost, and resulting in bigger capital market enhancement.

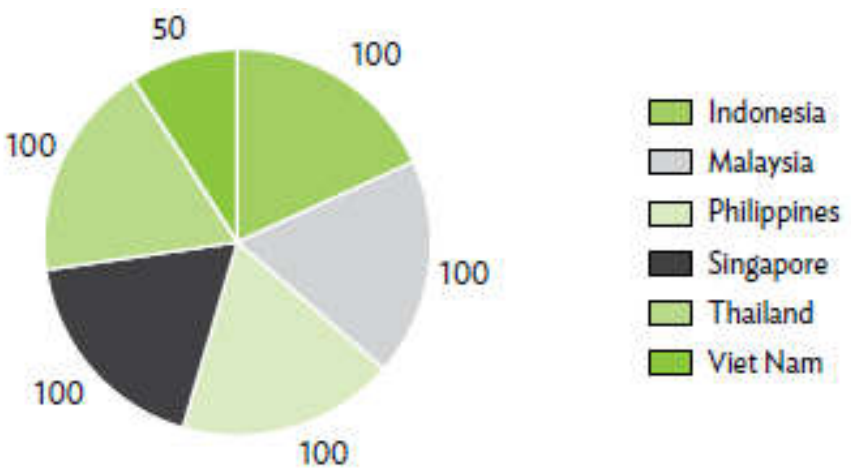

Figure 1 - The number of Public Companies Assessed in ASEAN Countries in 2014 Source: ACMF Working Group D Secretariat, 2014.

ASEAN Scorecard is continuously applied by ASEAN Public Companies as the diagnostic tool to overcome gaping in this practice; several regulators also have been considering the Scorecard to strengthen law or regulation on corporate governance. Figure 2 below will elaborate the average score of corporate governance of Indonesian public companies.

Figure 2 indicates an assessment from 2012; the progressive enhancement was displayed at all parts. From 2012 until 2014, rights of shareholders increase by $27.78 \%$; equitable treatment of all shareholders increases by $23.81 \%$; stakeholders' role increases by $28.30 \%$; disclosure and transparency increases by $6.56 \%$; and responsibility from the board of directors increases by $10.87 \%$. In 2014 , stakeholders' role got highest score (68) followed by disclosure and transparency (65). An item under the right of shareholders and responsibility of the board of directors get the lowest score.

There is score increase during the last three years on the rights of shareholders. In the 2014 assessment, Indonesian public companies reach an average of 4.95 points compared 
to 2013 by 4.15 points. Later on, it is important for Indonesian public companies to more strengthen an initiative to reserve the rights of shareholders.

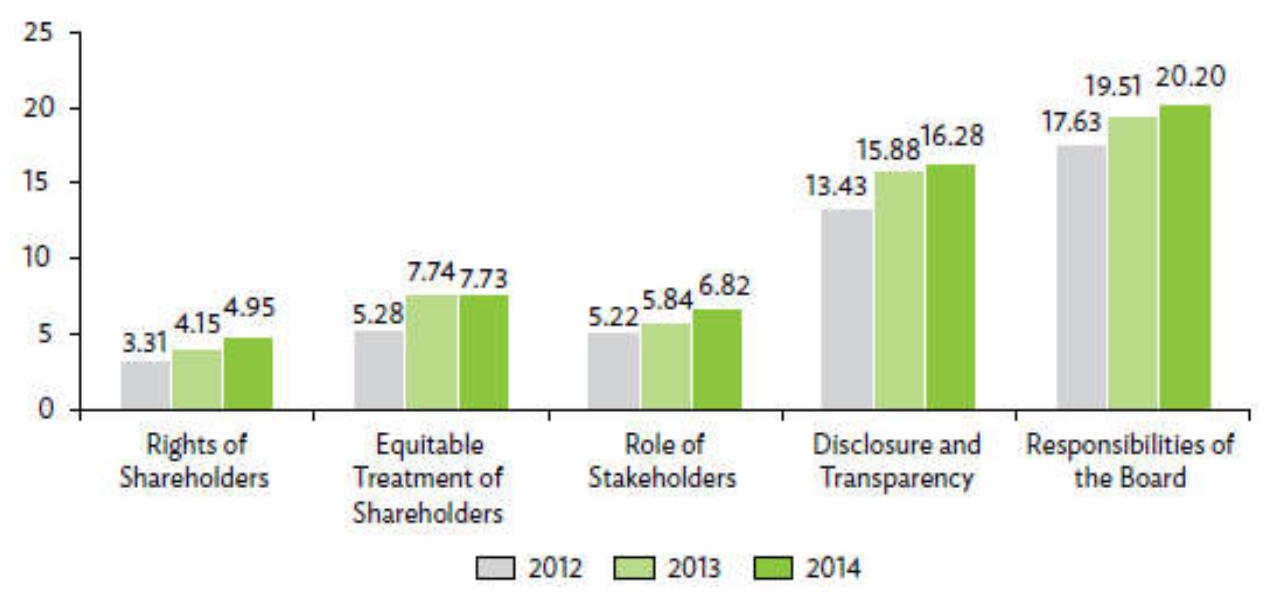

Figure 2 - The average score of Corporate Governance

The key factor of success that has given a contribution to the score enhancement of the rights of shareholders:

- Quality improvement of meeting summary;

- Publication of English version of information from shareholders general meeting;

- Strengthening regulatory framework to reserve the rights of shareholders.

The implementation of corporate governance to the Indonesian public companies shows the power of rights of shareholders. Rights of Shareholders are to participate in the policy that relates to the company and a basic change which is in accordance with:

- Amendment of company constitution;

- Authorization of additional shares;

- Transferring all or substantially the entire asset;

- Rights of shareholders to agree on the remuneration of the board of directors or board of commissioners;

- Shareholders general meeting is performed in an accessible location;

- Independent side is appointed by the board of directors or board of commissioners to evaluate the fairness of transaction cost of merger and acquisition.

Equitable treatment of all shareholders of public companies since 2012 shows a better score, the focus has to be put on:

- increasing the quality and information standard of shareholders general meeting;

- Notification issuance of shareholders general meeting in English;

- Strengthening regulatory framework and law enforcement.

Corporate governance performance for section "Equitable treatment of all shareholders shows a power on these matters:

- The existence of clear disclosure from voting rights for every class of share: amendment of company constitution; authorization of additional share; transferring all or substantially the entire asset;

- Availability of Proxy document;

- Availability of insider trading policy;

- Availability of transaction policy with related side.

Stakeholders' roles in the 2014 assessment reached $31 \%$ increase or 6.82 points from 2012. The role of stakeholders reaches the highest increase achieved year by year compared to other parts. Strengths in enhancing the role of stakeholders are characterized by:

- Availability of stakeholder interest policies in relation to: customer welfare; sustainable development; the rights of creditors; 
- Implementation of stakeholder policy is related to: welfare and customer health; sustainable development; the rights of creditors;

- Availability of company policy regarding: welfare, safety, and health of employees; employee development and training program.

The average score of Indonesian Public Companies disclosure is 16.28 points, with an increase of $2.51 \%$ compared to 2013 . Strengths in this area are marked by the enactment of OJK rules on transparency and disclosure. However, there are still some public companies that have not revealed some fundamental items for transparency and disclosure.

Supporting strengths in the area of disclosure and transparency are:

- Good corroboration disclosure structure;

- Good disclosure in terms of: the main risk; financial performance indicators; corporate objectives; training for director; the number of board meetings, including attending the board of commissioners meeting;

- Disclosure of related party transactions;

- Various modes of communication such as quarterly report and company website;

- Timeliness of the release of financial statements and annual reports.

Board of directors responsibility has an average score of 20.20 points, which has increased by 19.21 points compared to 2013. The board of directors' commitment to adopt corporate governance best practices is a major success factor in the upgrading of this area. The existing regulations play a role in ensuring that the board takes responsibility effectively and efficiently.

The achievement of corporate governance of Indonesian public companies in 2014 shows a smaller increase compared to 2013. Factors contributing to the low increase in 2014 can be attributed to the following:

- Low-level awareness for the ASEAN Corporate Governance Scorecard is especially small companies.

- Strong regulatory frameworks have not been implemented during the assessment period in 2014.

Environmental Performance. Environmental performance becomes an important thing in the AEC. The existence of free trade makes Indonesian companies able to defend their self against the foreign companies coming to Indonesia. In terms of environmental performance, environmental performing companies are of course will have an advantage than those who are not. Proper (2015) stated that if companies apply the system of good environmental management they will result in an efficiency. This will encourage companies to always create an innovation to result in their own values and make them become competitive advantage companies.

Adoption of the environmental issue in the management of the company will help to reduce the risk of the environment. It can be performed by applying eco-efficiency as being stated by Business Council for Sustainable development (WBCSD) that eco-efficiency helps to decrease the number of materials and energy, decrease pollution, and enlarge recycled materials, maximize the use of renewable natural resources, extend the lifetime of products and increase the intensity of service which is the key factor of eco-efficiency (ProLH, 2007). In order to establish a new market by embracing environmental issue, a company can apply Eco-design, Eco-sales, and marketing (Proper, 2015).

Environmental performance achievement as the result of company business activity will be reflected from environmental performance achieved by a company. The measure of environmental performance is different as depends on the institution or a country conducting a research. In Indonesia, a performance measure of environment applied by the ministry of environment is based on the PROPER.

The implementation of PROPER encourages the world of business to be consistent with the environment, applies the efficiency of resources usage and empowers the community and makes an innovation to manage the environment. Due to the fact that the company will be assessed for its performance based on efficiency in resource use, through the criteria of efficiency, emission reduction, conservation and reduction of water pollution 
load, 3R (reduce, reuse, and recycle) B3 waste and non-B3 solid waste and biodiversity protection, then it by itself makes the company more efficient in resource utilization so that the company puts some of that resources aside for the surrounding community with community empowerment programs.

The size of Proper is identical to the Green Economy, which according to the United Nation of Environment Program (UNEP) is a reconfiguration of businesses and infrastructure to generate better returns from natural resource, human being, economic capital while reducing greenhouse gas emissions, reducing waste, reducing extraction of natural resources and reducing social inequality (www.unep.org).

Table 1 indicates the assessment of the environmental performance of Indonesian public companies during the period of 2012 - 2015 showing an increase both in terms of the number of Public Companies assessed and environmental performance achievement which increases.

Table 1 - Indonesian Public Companies Environmental Performance Achievement

(Source: Proper, 2005)

\begin{tabular}{|c|r|r|r|r|r|r|}
\hline \multicolumn{1}{|c|}{ YEAR } & \multicolumn{1}{l|}{ BLACK } & \multicolumn{1}{l|}{ RLUE } & GREEN & \multicolumn{1}{c|}{ GOLD } & \multicolumn{1}{c|}{ TOTAL } \\
\hline $2002-2003$ & 2 & 20 & 52 & 8 & 0 & 82 \\
\hline $2003-2004$ & 22 & 64 & 99 & 9 & 0 & 194 \\
\hline $2008-2009$ & 41 & 116 & 182 & 21 & 0 & 360 \\
\hline $2008-2009$ & 9 & 73 & 305 & 45 & 0 & 432 \\
\hline $2008-2009$ & 32 & 118 & 385 & 40 & 1 & 576 \\
\hline $2009-2010$ & 47 & 154 & 433 & 54 & 2 & 690 \\
\hline $2010-2011$ & 48 & 233 & 603 & 106 & 5 & 995 \\
\hline $2011-2012$ & 79 & 295 & 805 & 119 & 12 & 1,310 \\
\hline $2012-2013$ & 17 & 551 & 1,099 & 113 & 12 & 1,792 \\
\hline $2013-2014$ & 21 & 516 & 1,224 & 121 & 9 & 1,891 \\
\hline $2014-2015$ & 21 & 529 & 1,406 & 108 & 12 & 2,076 \\
\hline
\end{tabular}

The increase in the number of public companies that follow the environmental performance assessment program from year to year increases. This is in line with the increase in the number of companies that meet the compliance criteria in the applicable regulations. This demonstrates the increase of Public Company awareness to run a business that is not only pursuing profit but also paying attention to environmental management as required.

The number of companies which its environmental performance gets bigger assessed from the achievement of the Blue criteria in 2012 to 2013 has increased sharply. This is due to the efforts of the company in complying with the rules, besides the expansion of the scope of the companies that participated in the rating program conducted by the Ministry of Environment.

The achievement of green criteria is an effort made by the company by undertaking environmental management beyond compliance through the implementation of environmental management systems and utilizing resources efficiently and performing social responsibility well (www.menlh.go.id/proper). Compared to the achievement of the blue criteria, the number of companies performing under the green criteria is smaller, let alone companies that get gold ratings. 
The achievement of green and gold criteria in 2010 to 2015 was not too significant. This illustration shows that in general the environmental performance achievement of public companies is still on the blue criterion or meets the required regulations only.

Environmental performance achievement is the result of implementing voluntary initiatives to integrate social and environmental issues in today's business, in the hope of sustainability. Companies with good environmental performance will certainly support sustainable development. For that matter, sustainability will be increasingly important so that this has changed the direction of business (UNGC, 2010).

As sustainability is being recognized as a source of competitive advantage, organizations seek to achieve economic sustainable performance, social and environmental, although economic growth remains at the core of business (Hart and Milstein, 2003; Porter and Kramer, 2006). Thus, business sustainability efforts are mainly directed to expand the market and keep business as usual. The implementation of MEA in 2015 became a place to expand the market of Indonesian companies.

Other environmental performance measures besides PROPER are those issued by Yale University known as the Environmental Performance Index (EPI). It is grouped into 9 categories of issues: health impact, air quality, water and sanitation, water resources, agriculture, forests, fisheries, habitats and biodiversity, and climate and energy, with a total of 20 indicators. (www.epi.yale.edu).

Table 2 indicates environmental performance achievements of ASEAN countries from 2014 to 2016.

Table 2 - Environmental Performance Index of ASEAN Countries

\begin{tabular}{|l|c|c|c|c|c|}
\hline \multirow{2}{*}{ COUNTRY } & \multicolumn{2}{|c|}{ EPI 2016 } & \multicolumn{2}{c|}{ EPI 2014 } & \multirow{2}{*}{ RATING CHANGES } \\
\cline { 2 - 5 } & RATING & SCORE & RATING & SCORE & -10 \\
\hline Singapore & 14 & 87.04 & 4 & 81.78 & -12 \\
\hline Malaysia & 63 & 74.23 & 51 & 59.31 & 48 \\
\hline Philippines & 66 & 73.70 & 114 & 44.02 & -13 \\
\hline Thailand & 91 & 69.54 & 78 & 52.83 & -61 \\
\hline Brunei Darussalam & 98 & 67.86 & 37 & 66.49 & 5 \\
\hline Indonesia & 107 & 65.85 & 112 & 44.36 & 5 \\
\hline Vietnam & 131 & 58.50 & 136 & 38.17 & -1 \\
\hline Cambodia & 146 & 51.24 & 145 & 35.44 & -21 \\
\hline Laos & 148 & 50.29 & 127 & 40.37 & 11 \\
\hline Myanmar & 153 & 48.98 & 164 & 27,44 & \\
\hline
\end{tabular}

Table 3 - Score Indicator of Indonesia EPI

\begin{tabular}{|l|c|c|}
\hline \multicolumn{1}{|c|}{ Indicator of EPI } & 2016 & 2014 \\
\hline Rank & 107 & 112 \\
\hline Score of EPI & 65.85 & 44.36 \\
\hline EH - Health Impacts & 75.43 & 67.55 \\
\hline EH - Air Quality & 80.36 & 75.31 \\
\hline EH -Water and Sanitation & 7466 & 2429 \\
\hline EV - Water Resources & 12.69 & 0.02 \\
\hline EV - Agriculture & 84.31 & 51.85 \\
\hline EV - Forests & 12.96 & 7.75 \\
\hline EV - Fisheries & 23.59 & 25.8 \\
\hline EV- Biodiversity and Habitat & 81.62 & 78.08 \\
\hline EV - Climate and Energy & 81.59 & 45.25 \\
\hline
\end{tabular}


The rating changes of environmental performance achievement show the existence of changeover in the environmental management. There are four countries which undergo rating enhancement; Philippines, Indonesia, Vietnam, and Myanmar. Indonesia has been experiencing EPI rating enhancement from 112 with the score of 44.36 in 2014 and 107 with the score of 65.85 in 2016. This change in rating indicates an improvement in the environmental performance index achieved by up 5 ranks in 2016.

Table 3 indicates score achievement of each indicator of Indonesia Environmental Performance Indicators (EPI).

The increase of EPl's score and rating shows the existence of effort to repair environmental management from 2014 to 2016. Each of EPI indicators in 2014 compared to 2016 shows an enhancement so that the general score also increases. This shows that there is a betterment effort of environmental performance in the Asean Economic Community.

\section{CONCLUSION}

Based on the discussion above, several conclusions can be made as follows: corporate governance of Indonesian public companies shows an increase during the observation so that can be concluded that public companies are ready to face the AEC; environmental performance of Indonesian public companies measured by PROPER and EPI shows an improvement during the observation period so that can be concluded that those companies are ready to face the AEC.

\section{REFERENCES}

1. Ab-Rahim, Rossazana. 2014 Environmental Performance of ASEAN Countries: A Data Envelopment Analysis Approach. Journal of Economic Policy \& Research. Vol. 10 Issue 1, pp. 98-108.

2. Albelda, E. 2011. The role of management accounting practices as facilitators of the environmental management Evidence from EMAS organisations. Sustainability Accounting, Management and Policy Journal Vol. 2 No. 1, 2011 pp. 76-100.

3. Effendi, M. Arief. 2009. Good Corporate Governance; Teori dan Implikasinya. Jakarta; Salemba Empat.

4. Gunawan, J. 2015. Corporate Social Disclosure in Indonesia; Stakeholders influence and motivation, Social Responcibility Journal, VI.11. No.3.

5. Hart, S.L. and Milstein, M.B. 2003. Creating sustainable value. Academy of Management Executive, Vol. 17 No. 2, pp. 56-67.

6. OECD Report, 2004. The OECD Principle of Corporate Governance. The Organization for Economic Cooperation and Development, Paris.

7. ProLH, GTZ, Panduan Penerapan Eko-efisiensi Usaha Kecil dan Menengah Sektor Batik. Jakarta: Kementrian Negara Lingkungan Hidup Republik Indonesia, 2007.

8. Said, M.R. Sulaiman, M. and Ahmad N. 2014. Environmental information usefulness to Stakeholders: Empirical Evidence from Malaysia. Social Responsibility Journal. Vol. 10 No. 2, 2014, pp. 348-363.

9. Smolo and Smajic, 2011. Recent fiasco in Qatar: the need for good governance. ISRA Bulletin, Vol. 8, pp. 3-4.

10. The ASEAN Secretariat Jakarta. 2015. A Blueprint for Growth ASEAN Economic Community 2015: Progress and Key Achievements.

11. Yacoob, $\mathrm{H}$ and Basiuni, J. 2014. Corporate governance model of a state-owned enterprise: evidence from an Asian emerging market. Corporate Governance . Vol. 14 No. 4, 2014, pp. 504-514.

12. www.asean.org. Asean corporate governance scorecard; country report and assessment 2014. Retrieved on 24 Agustus 2016.

13. www.asean.org. Asean corporate governance scorecard; country report and assessment 2015. Retrieved on 24 Agustus 2016. 
14. www.asean.org. A Blueprint for Growth ASEAN Economic Community 2015: Progress and Key Achievements. Retrieved on 24 Agustus 2016.

15. www.ojk.go.id. Roadmap tata kelola perusahaan Indonesia. Retrieved on 24 Agustus 2016.

16. www.menlh.go.id/proper/ Publikasi Proper 2015. Retrieved on 23 November 2016

17. www.epi.yale.edu. 2016 Report - Environmental Performance Index - Yale University. Retrieved on 28 Desember 2016. 